\title{
Assessment methodology of backwash in pressurized sand filters
}

\author{
Fábio P. de Deus ${ }^{1}$, Roberto Testezlaf ${ }^{2} \&$ Marcio Mesquita ${ }^{3}$ \\ ${ }^{1}$ Universidade Federal de Lavras/Departamento de Engenharia. Lavras, MG. E-mail: fabio.ponciano@deg.ufla.br (Corresponding author) \\ ${ }^{2}$ Universidade Estadual de Campinas/Faculdade de Engenharia Agrícola. Campinas, SP. E-mail: bob@feagri.unicamp.br \\ ${ }^{3}$ Universidade Federal de Goiás/Escola de Agronomia/Departamento de Engenharia de Biossistemas. Goiânia, GO. E-mail: marciomes@gmail.com
}

\section{Key words:}

localized irrigation

water treatment

emitters clogging

\begin{abstract}
A B S T R A C T
The objective of this study was to apply a methodology based on sampling sand from contaminated filter beds, to evaluate the performance of the backwash process in pressurized sand filters used in irrigation. Backwash trials were conducted in an experimental module with three new sand filters of the same commercial model. The evaluations were conducted after filtration processes performed using four filtration rates and three separate sand particle sizes (fine - $0.55 \mathrm{~mm}$; medium - $0.77 \mathrm{~mm}$, and coarse sand - $1.04 \mathrm{~mm}$ diameter), repeated in three subsequent cycles. After reaching a fixed expansion of $25 \%$ of the filter bed height, the backwash processes were performed for $15 \mathrm{~min}$. Backwash cleaning efficiency was evaluated in all trials based on the mass of removed solids for different filter bed layers and throughout the entire filter bed. The backwash assessment methodology is effective and has potential to be a practical tool for farmers in the evaluation of the performance of pressurized sand filters used in irrigation.
\end{abstract}

\section{Palavras-chave:}

irrigação localizada

tratamento da água

entupimento de emissores

\section{Metodologia de avaliação do processo de retrolavagem em filtros de areia pressurizados}

\begin{abstract}
R E S U M O
Propôs-se, neste trabalho, aplicar uma metodologia baseada em amostragens de areia de leitos filtrantes contaminados para avaliar o desempenho do processo de retrolavagem em filtros de areia pressurizados utilizados na irrigação. Os ensaios de retrolavagem foram conduzidos em um módulo experimental constituído de três filtros novos de areia e de um mesmo modelo comercial. As avaliações foram conduzidas após processos de filtração realizados com o emprego de quatro taxas de filtração em três granulometrias de areia, separadamente (areia fina, 0,55 $\mathrm{mm}$; média, 0,77 $\mathrm{mm}$ e grossa, 1,04 $\mathrm{mm}$ de diâmetro) repetidos em três ciclos de filtração subsequentes; após atingir uma expansão fixa de $25 \%$ da altura leito filtrante, as retrolavagens foram processadas por $15 \mathrm{~min}$; a eficiência de limpeza da retrolavagem foi avaliada em todos os ensaios a partir da massa de sólidos removidos para as diferentes camadas do leito filtrante e para a camada, por inteiro. A metodologia de avaliação do processo de retrolavagem é eficaz e possui potencial para ser uma ferramenta prática para o agricultor na avaliação do desempenho de filtros de areia pressurizados utilizados na irrigação.
\end{abstract}




\section{INTRODUCTION}

The performance of the filtration process in pressurized sand filters used in localized irrigation depends, among other factors, on the quality of the backwash operation (Brouckaert et al., 2006). Performing a backwash is a requirement in the operation of these devices due to the increment in their pressure loss with the increasing filter bed contamination and consequent reduction in the efficiency of removal of suspended particles (Elbana et al., 2012).

To perform a backwash, it is necessary to conduct previously filtered water through one or more filters of the filtration set, in the opposite direction of the filtration process (usually upward) with enough velocity to promote an adequate level of expansion and disturbance of the filter bed (Kau \& Lawler, 1995; Turan et al., 2003; Ramirez et al., 2011). In filter bed expansion during the backwash, the required value of superficial velocity increases with the increment in the desired expansion level and with the filter media granulometry, varying its magnitude between the different construction models of sand filter drains (Ramirez et al., 2011; Mesquita et al., 2012).

Poorly performed backwash reduces filter bed porosity because it does not fully remove the obstruction of pores by already adhered particles, causing increase in the pressure differential of the device and reduction of removal efficiency in the subsequent filtration process (Staden \& Haarhoff, 2011). Enciso-Medina et al. (2011) point out that the incorrect definition of intervals and durations of backwash processes in sand filters is the main cause of low performance in successive filtrations.

The evaluation of backwash performance in pressurized sand filters used in irrigation is a complex procedure, due to the variability of the operating conditions and the number of factors intervening in the phenomenon, which still requires deepening in methodology and normatization. Even the norm of ASABE (1994), one of the few references that guide the procedures of evaluation of sand filters, does not present methodologies to characterize the backwash process and determine the cleaning efficiency of these devices. One methodological option in backwash evaluation would be the use of sand samplings, a method used in the evaluation of slow filters applied to the treatment of water for urban supply, as highlighted by Staden \& Haarhoff (2011).

In this context, this study aimed to evaluate the methodology of sampling of sand from contaminated filter beds in pressurized sand filters used in irrigation, with possibility of application in the evaluation of performance in backwash processes.

\section{Material ANd Methods}

The study was carried out in an experimental module (Figure 1A) composed of three new sand filters (FA07Hidrosolo") (Figure 1B) mounted in parallel (F1, F2 and F3) and connected to a fourth filter (FR), used to filter the water for the individual cleaning (backwash) of the evaluated filters. The experimental module was also composed of: needle and gate valves, electromagnetic flow rate sensors (one per filter) and pressure transducers (two per filter) connected to integral pressure testers (two per filter - inlet and outlet), installed according to the norm of ASABE (1994) for positioning in pipes. All the instruments of the module were connected to a data acquisition system (National Instruments') and a laptop, managed by a computational interface developed using the program Labview.

The water used in the experiment came from a tank close to the experimental area, which belongs to a micro-watershed with predominance of dystroferric Red Latosol, with $5.20 \pm$ $3.09 \mathrm{mg} \mathrm{L}^{-1}$ of total suspended solids (TSS).

To evaluate backwash performance, it was necessary to dirty the filter bed of the analyzed filters (F1, F2 and F3) by applying four filtration rates (TF20 $-20 \mathrm{~m}^{3} \mathrm{~m}^{-2} \mathrm{~h}^{-1}$, TF40 - 40 $\mathrm{m}^{3} \mathrm{~m}^{-2} \mathrm{~h}^{-1}$, TF60 $-60 \mathrm{~m}^{3} \mathrm{~m}^{-2} \mathrm{~h}^{-1}$ and TF75 $\left.-75 \mathrm{~m}^{3} \mathrm{~m}^{-2} \mathrm{~h}^{-1}\right)$ in three silica sand granulometries (G1, G2 and G3), with a 4-h filtration in each experimental combination.

In order to evaluate the performance of the filters in backwash processes subsequent to the first one, the filtering procedures were repeated twice more, on days following the trials, called filtration cycles $\left(\mathrm{C} 1-1^{\text {st }}\right.$ day of trial, $\mathrm{C} 2-2^{\text {nd }}$ day of trial and $\mathrm{C} 3-3^{\text {rd }}$ day of trial).

The sand granulometries, referred to as G1 (fine: effective diameter $-\mathrm{D}_{10}=0.55 \mathrm{~mm}$ and uniformity coefficient $-\mathrm{UC}=$ 1.34), G2 (medium: $\mathrm{D}_{10}=0.77 \mathrm{~mm}$ and $\mathrm{UC}=1.28$ ) and $\mathrm{G} 3$

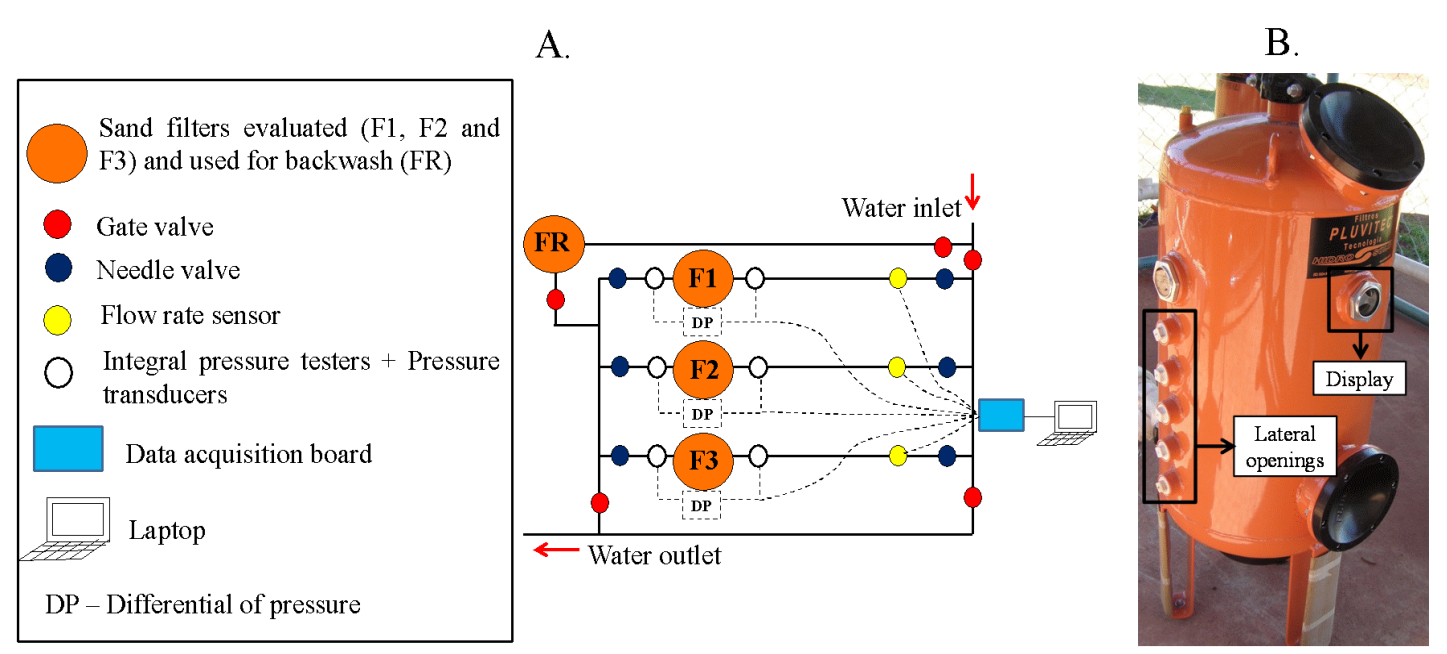

Figure 1. Layout of installation of the experimental module and its devices (A) and the evaluated model of filter, with detail of the structural modifications performed (B) 
(coarse: $\mathrm{D}_{10}=1.04 \mathrm{~mm}$ and $\mathrm{UC}=1.36$ ), were used with a fixed filter bed height of $0.35 \mathrm{~m}$, according to the recommendations of the manufacturer. The combination of filtering conditions resulted in 36 trials ( $4 \mathrm{TF} \times 3 \mathrm{G} \times 3 \mathrm{C}$ ), which corresponded to an identical number of backwash performance analyses.

After the filtration step, backwash trials were performed in each filter individually and the procedure consisted in applying a flow rate from the fourth filter of the module (FR) in the opposite direction of the filtration process, in order to generate a filter bed expansion of $25 \%$, according to the guidelines of Brouckaert (2004), which corresponded to the height of $0.44 \mathrm{~m}$. To standardize the same level of expansion of the layer between the backwash trials, threaded circular acrylic displays (50.4 mm of diameter), resistant to pressure (Reimidas Industrial Ltda.) (Figure 1B) were installed at the same level of the desired expansion value (Figure 1B).

Since the trials were performed using three sand granulometries separately in order to promote the same expansion level in the backwash processes it was necessary to increase water superficial velocity (Vs - relationship between flow rate and the cross-section area of water flow in the filter) with the increase in sand granulometry, as recommended by Ramirez et al. (2011). Thus, a mean Vs of $79.79 \mathrm{~m} \mathrm{~h}^{-1}$ (Coefficient of variation $-\mathrm{CV}=0.73 \%$ ) was applied in $\mathrm{G} 1$, a mean Vs of $94.9 \mathrm{~m} \mathrm{~h}^{-1}(\mathrm{CV}=1.85 \%)$ was applied in $\mathrm{G} 2$ and a mean Vs of $92.24 \mathrm{~m} \mathrm{~h}^{-1}(\mathrm{CV}=3.28 \%)$ was applied in $\mathrm{G} 3$. For the use of sand with larger granulometry (G3), it was not possible to reach the same expansion level of the other granulometries, because the motor pump set did not generate enough flow rate for the desired expansion.

Backwash was evaluated based on the collection of sand samples at different depths inside the filter bed (four sampling points in the filter bed profile). For this, threaded lateral openings were installed in each filter to facilitate sand collection in the cross section of the evaluated bed (Figure 1B). This sampling was performed before and after backwashing, with the aid of a device used as a grain sampler (drill-type) dimensioned to be inserted through an opening with diameter of approximately $25 \mathrm{~mm}$ and allow the collection of at least 60 $\mathrm{mL}$ of sand composed of the entire cross section of the filter. The four sampled layers were called 1 (referring to the surface of the filter bed, from 0 to $8.75 \mathrm{~cm}$, where "0" corresponds to the filter bed upper surface), 2 (8.75-17.5 cm), 3 (17.5-26.25 $\mathrm{cm}$ ) (intermediate points) and 4 (filter bed bottom, 26.25 to $35 \mathrm{~cm}$ ). The sand samples collected in the three filters (F1, F2 and F3), for each depth and trial conditions, were mixed to generate a composite sample.

Cleaning efficiency was used as a backwash evaluation index, considering the difference of TSS contained in the sand sample, before and after backwashing. The amount of SST contained in the sand was determined using the procedure developed by Staden \& Haarhoff (2011), called "Cylinder Inversion Method", to obtain water samples for analyses. A homogenized $60-\mathrm{mL}$ sand sample, composed of the collections from three filters for a certain depth and experimental combination, was placed in a $250 \mathrm{~mL}$ graduated cylinder. After the addition of $100 \mathrm{~mL}$ of clean water, this container was sealed and manually inverted 20 times, pausing the inversions to allow the sand to settle at its ends. After this procedure, the suspension was drained in a $500 \mathrm{~mL}$ Erlenmeyer flask and the initial steps were repeated with the same sand sample, for more four times, until obtaining the total volume of $500 \mathrm{~mL}$ in the Erlenmeyer flask. A $100 \mathrm{~mL}$ water sample was collected from the total volume for later determination of SST concentration, using the methodology proposed by APHA (1995).

The mass of solids after the filtration trials $\left(\mathrm{MS}_{\mathrm{Fi}}\right)$, in each individual layer of the bed (degree of soiling), was quantified using Eq. 1 and, based on its sum, the total mass of solids present in the filter bed $\left(\mathrm{MS}_{\text {Ftotal }}\right)$ was estimated.

$$
\mathrm{MS}_{\mathrm{Fi}}=0.0183 \cdot \mathrm{TSS}_{\mathrm{A}_{\mathrm{Ri}}}
$$

where:

$\mathrm{MS}_{\mathrm{Fi}}$ - mass of solids present in the filter bed after filtration trial (degree of soiling) in each fraction of volume of the filtering layer i $(\mathrm{g})$; and

$\mathrm{TSS}_{\mathrm{ARi}}$ - concentration of total suspended solids $\left(\mathrm{mg} \mathrm{L}^{-1}\right)$ present in a $60 \mathrm{~mL}$ sand sample from the filtering layer $i$, before backwashing or after filtration.

Eq. 2 was used to determine the mass of solids removed in each backwash trial in the filter bed individual layers $\left(\mathrm{MS}_{\mathrm{Ri}}\right)$ and, based on its sum, the total mass of solids removed in the backwash process $\left(\mathrm{MS}_{\mathrm{Rtotal}}\right)$ was estimated.

$$
\mathrm{MS}_{\mathrm{Ri}}=\mathrm{MS}_{\mathrm{Fi}}-\mathrm{MS}_{\mathrm{DRi}}=0.0183 \cdot\left(\mathrm{TSS}_{\mathrm{ARi}}-\mathrm{TSS}_{\mathrm{DRi}}\right)
$$

where:

$\mathrm{MS}_{\mathrm{Ri}}$ - mass of solids removed from the sand in the backwash process, in each fraction of volume of the filtering layer i $(\mathrm{g})$;

$\mathrm{MS}_{\mathrm{DRi}}$ - mass of solids present in the filter bed after backwash trials, in each fraction of volume of the filtering layer i (g);

TSS $_{\mathrm{DRi}}$ - concentration of total suspended solids $\left(\mathrm{mg} \mathrm{L}^{-1}\right)$ present in a $60 \mathrm{~mL}$ sand sample from the filtering layer i after backwashing.

Backwash cleaning efficiency was estimated for the different depths of the filtering layer $\left(\mathrm{E}_{\mathrm{Li}}\right)$ (Eq. 3) and for the entire filter bed $\left(\mathrm{E}_{\mathrm{L}}\right)($ Eq. 4$)$.

$$
\mathrm{E}_{\mathrm{Li}}=\left[\frac{\mathrm{MS}_{\mathrm{Fi}}-\mathrm{MS}_{\mathrm{DRi}}}{\mathrm{MS}_{\mathrm{Fi}}}\right] \cdot 100=\frac{\mathrm{MS}_{\mathrm{Ri}}}{\mathrm{MS}_{\mathrm{Fi}}} \cdot 100
$$

where:

$\mathrm{E}_{\mathrm{Li}} \quad$ - cleaning efficiency for a certain depth i evaluated in the filtering layer (\%).

$$
\mathrm{E}_{\mathrm{L}}=\left[\frac{\mathrm{MS}_{\mathrm{Rtotal}}}{\mathrm{MS}_{\mathrm{Ftotal}}}\right] \cdot 100
$$

where:

$\mathrm{E}_{\mathrm{L}}$ - cleaning efficiency for the entire filter bed (\%). 
In terms of analysis, the obtained results of backwash cleaning efficiency for the different trial conditions were analyzed graphically.

\section{Results AND Discussion}

There was a difference in the contamination between the evaluated filter bed layers for the use of finer sand granulometry $(\mathrm{G} 1)$, especially at the highest filtration rate (TF75), resulting in greater amount of solids adhered to the superficial layers (Figure 2). Rodgers et al. (2004) comment that the accumulation of suspended solids on filtering media surface may determine its clogging, significantly reducing the saturated hydraulic conductivity from the top of the filter bed; thus, the beginning of bed fluidization in the backwash may show additional resistance. In coarser sand granulometries (G2 and G3), associated with the lowest filtration rates (TF20 and TF40), the deepest layers showed greater amount of adhered solids, demonstrating the prevalence of the effect of sieving on particle retention for the finer granulometry and of sedimentation and/or adhesion and/or cohesion for the granulometries of larger effective diameter (Testezlaf, 2008).

For the evaluated sand granulometries, the mass of solids present in the bed decreased along the depth until layer 3, increasing in layer 4 for almost all filtration rates, except for the combination G1 TF20 and G1 TF75, which demonstrates that, in the filtration process, there is a displacement of particles from more superficial layers to the deepest ones, where the drains are located. At the same time, it can be claimed that filter bed contamination is not uniform between the layers.

The reduction in the mass of solids adhered to the filter bed along the three filtration cycles of the experiment shows a probable decrease in the removal capacity of the filter bed (Figure 3). This may be associated with failures in the cleaning of sand filters and may lead to filter bed deterioration, compromising the subsequent filtrations (Brouckaert et al., 2006). Such behavior was different from that observed by Kau \& Lawler (1995), who highlighted the return of the initial removal conditions of the bed after the backwash procedure.
G1
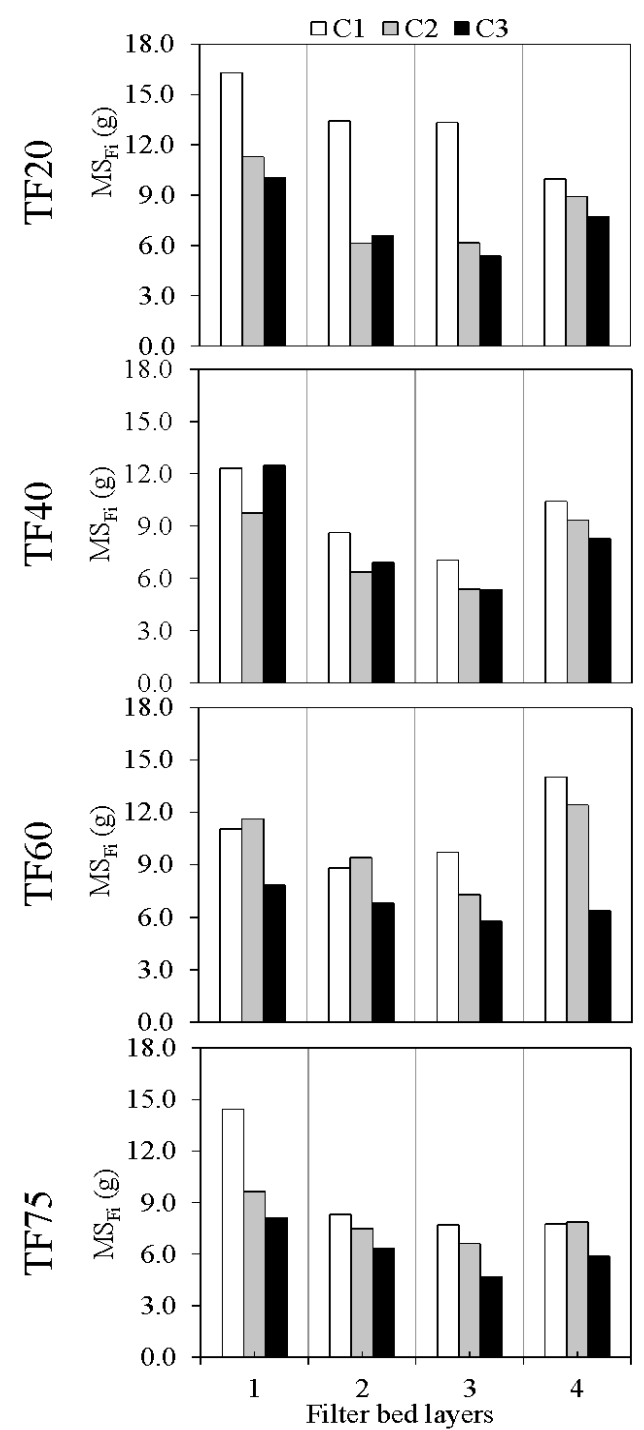

G2
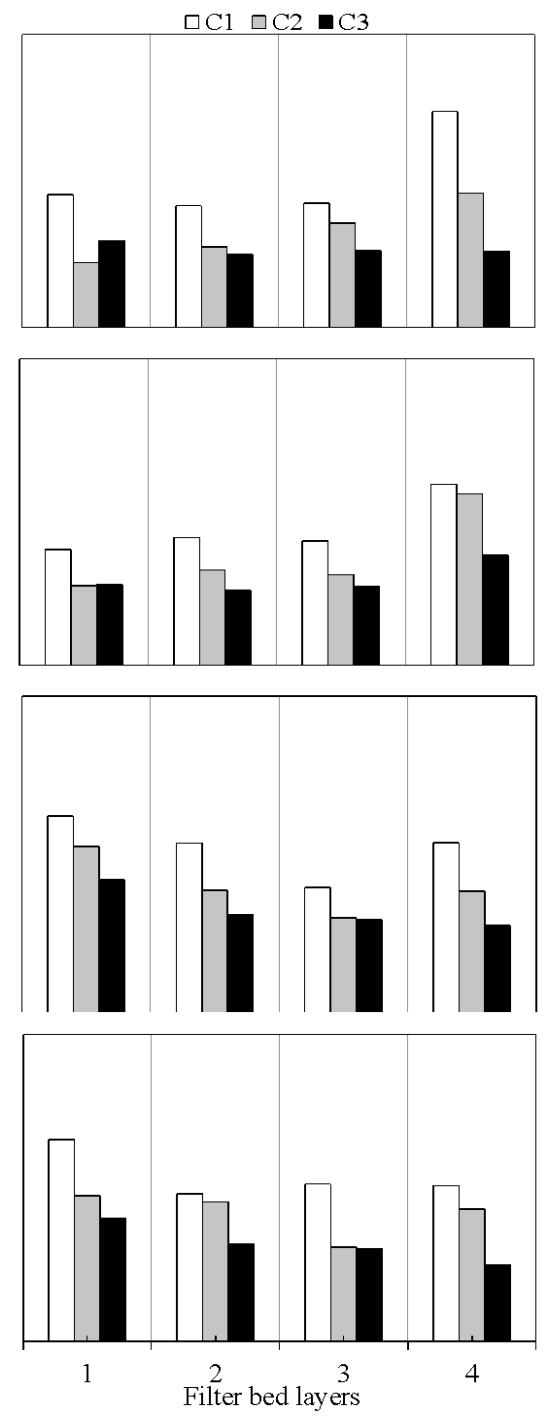

G3
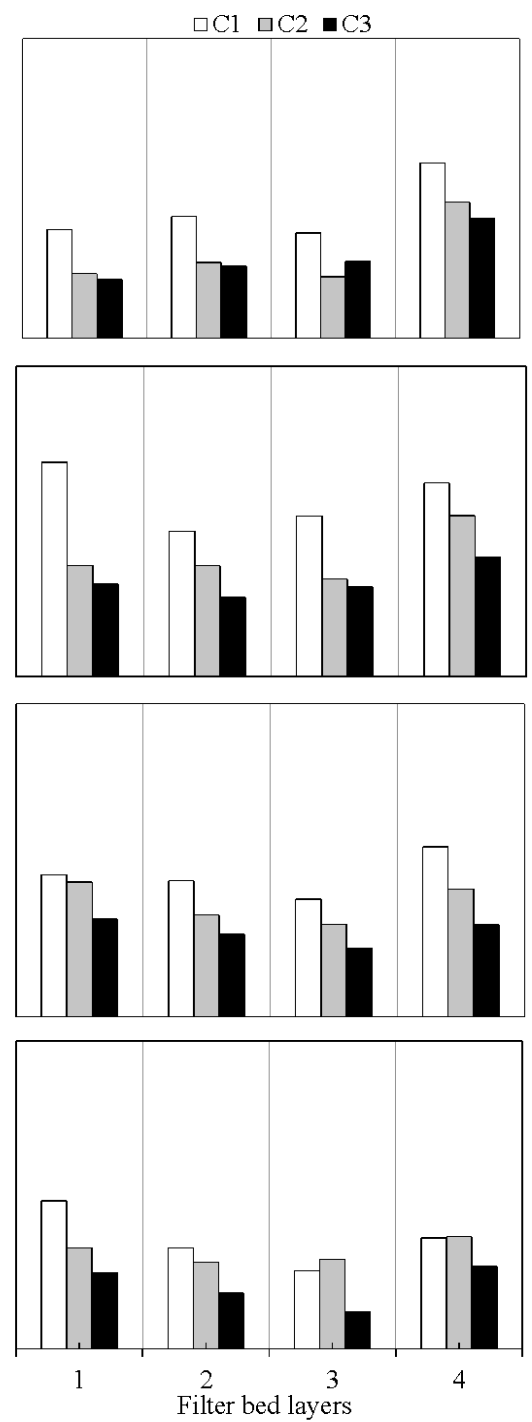

Figure 2. Behavior of mass of solids present in the filter bed after filtration (before backwashing) in different filter bed layers $\left(\mathrm{MS}_{\mathrm{Fi}}\right)$ for different combinations of sand granulometry (G1, G2 and G3), filtration rates (TF20, TF40, TF60 and TF75) and filtration cycles (C1, C2 and C3) 
G1

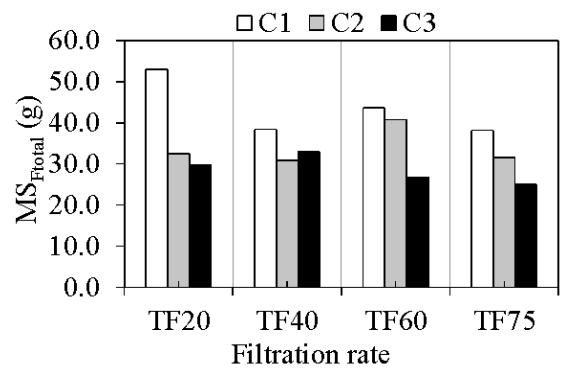

G2

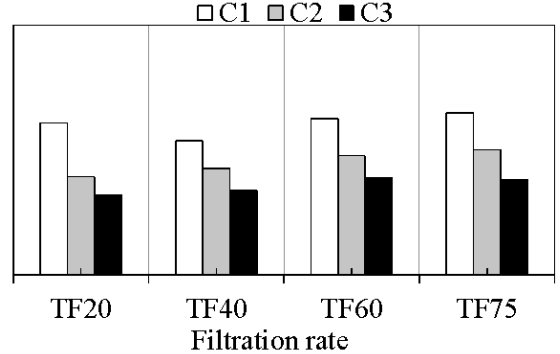

G3

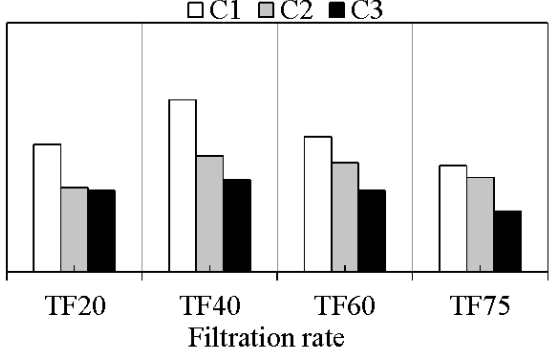

Figure 3. Behavior of total mass of solids present in the filter bed after filtration (before backwashing) $\left(\mathrm{MS}_{\text {Ftotal }}\right.$ ), for different combinations of sand granulometry (G1, G2 and G3), filtration rates (TF20, TF40, TF60 and TF75) and filtration cycles (C1, C2 and C3)

The most superficial layer of the filter bed (layer 1) showed the highest values of cleaning efficiency, of the order of $77.1 \%$, in comparison to the deepest layer (layer 4), which may be attributed to the more favorable position of this layer for the removal of retained solids (lower resistance to displacement), as well as to the heterogeneous and insufficient bed expansion for the fluidization of its entire thickness, making it difficult the removal of particles from deeper layers (Figure 4). Mesquita (2014) observed that the structural project and the spatial arrangement of the drains at the bottom of the filter are essential to reaching uniform filter bed expansions, guaranteeing homogeneous removal of contaminants between the layers. In the evaluation of the same model of drain used in this experiment, using the CFD (computer fluid dynamic) tool, Mesquita (2014) detected regions at the base of the drains with absence of flow, preventing the occurrence of filter bed expansion in these regions and, consequently, its cleaning. Santos et al. (2013) pointed out that different drainage systems led to different behaviors of the flow lines inside the filter and may interfere with filter bed expansion and with the loss of pressure of the backwash process. As to the possibility of the differenced contamination interfering with the values of backwash cleaning efficiency, Brouckaert et al. (2006) highlight that non-uniform contaminations of the filter bed during filtration lead to non-uniform bed fluidizations, compromising the effectiveness in the cleaning of the device. Hence, there
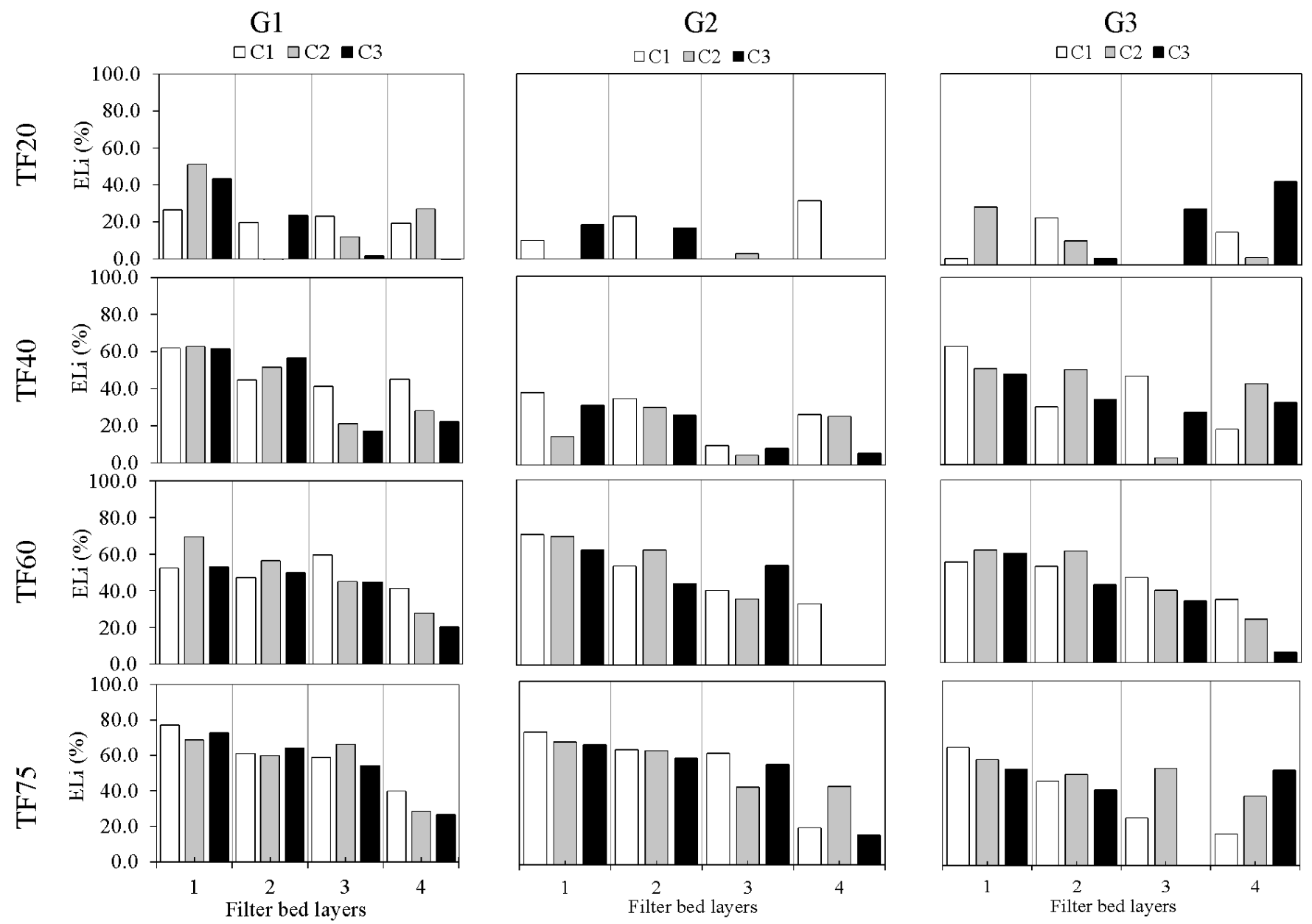

Figure 4. Behavior of cleaning efficiency in different filter bed layers $\left(\mathrm{E}_{\mathrm{L} i \mathrm{i}}\right)$, for different combinations of filtration cycles (C1, C2 and C3), sand granulometries (G1, G2 and G3) and filtration rates (TF20, TF40, TF60 and TF75) 
G1

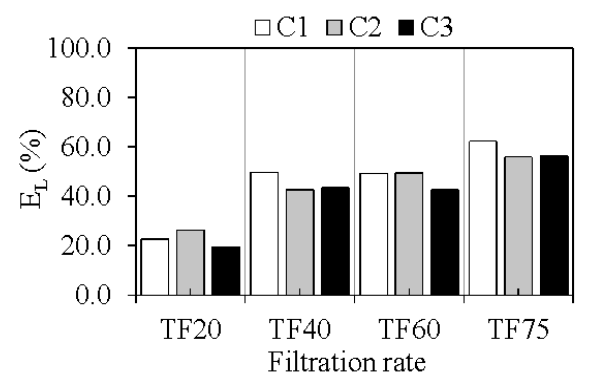

G2

$\square \mathrm{C} 1 \square \mathrm{C} 2 \mathbf{\mathrm { C }} 3$

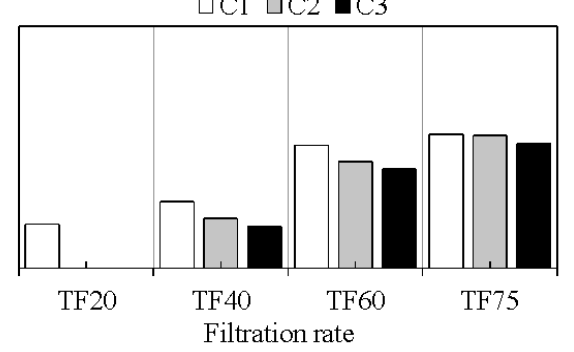

G3

$\square \mathrm{C} 1 \quad \square \mathrm{C} 2 \quad \mathrm{aC} 3$

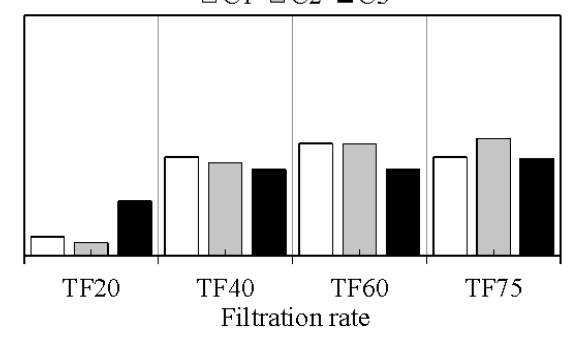

Figure 5. Behavior of cleaning efficiency considering the entire filter bed $\left(\mathrm{E}_{\mathrm{L}}\right)$, as a function of different filtration cycles (C1, C2 and C3), sand granulometries (G1, G2 and G3) and filtration rates (TF20, TF40, TF60 and TF75)

are various hypotheses inherent to the differentiation in the removal of particles in the backwash process, and all of them converge to the project of the device.

The filtration trials using the highest filtration rates promoted the highest values of cleaning efficiency, considering the entire filter bed (Figure 5). A possible explanation, according to Brouckaert et al. (2006), is that the highest value of cleaning efficiency is due to the increment in the mass of residues in the filtering media in the filtration process. In this context, the increase in filtration rate promotes increment in the removal of suspended solids, directly reflecting in the cleaning efficiency of the device.

On the other hand, for a fixed filtration rate, there was no difference in $\mathrm{E}_{\mathrm{L}}$ between the evaluated sand granulometries, although the trials using the coarsest granulometry (G3) were not performed with superficial velocities that allowed reaching the same expansion level of the other granulometries. Comparing the results between filtration cycles, $\mathrm{E}_{\mathrm{L}}$ remained virtually constant, although the cycle $\mathrm{C} 1$ showed some values higher than those of subsequent cycles.

\section{Conclusion}

The backwash assessment methodology is effective and has potential to be a practical tool for irrigation farmers in the evaluation of performance of pressurized sand filters used in irrigation.

\section{ACKNowledgments}

To the São Paulo Research Support Foundation - FAPESP, for funding the Research Project.

\section{Literature Cited}

APHA - American Public Health Association -. Standard methods for the examination of water and wastewater. 19.ed., Washington: APHA/AWWA/WPCF. 1995. 798p.

ASABE - American Society Agricultural and Biological Engineers ANSI/ASAE S539 Media filters for irrigation - Testing and performance reporting. 1994. 7p.

Brouckaert, M. B. Hydrodynamic detachment of deposited particles in fluidized bed filter backwashing. Atlanta: GIT, 2004. 383p. Doctoral Thesis
Brouckaert, M. B.; Amirtharajah, C. J.; Brouckaert, C. J.; Amburgey, J. E. Predicting the efficiency of deposit removal during filter backwash. Water SA, v.32, p. 633-640, 2006.

Elbana, M.; Cartagena, F. R. de; Puig-Bargués, J. Effectiveness of sand media filters for removing turbidity and recovering dissolved oxygen from a reclaimed effluent used for micro-irrigation. Agricultural Water Management, v.111, p.27-33, 2012. http:// dx.doi.org/10.1016/j.agwat.2012.04.010

Enciso-Medina, J.; Multer, W. L.; Lamm, F. R. Management, maintenance and water quality effects on the long-term performance of subsurface drip irrigation systems. Applied Engineering and Agriculture, v.27, p.969-978, 2011. http://dx.doi.org/10.13031/2013.40633

Kau, S. M.; Lawler, D. F. Dynamics of dep-bed filtration: Velocity, depth, and media. Journal of Environmental Engineering, v.121, p.850-859, 1995. http://dx.doi.org/10.1061/(ASCE)07339372(1995)121:12(850)

Mesquita, M. Desenvolvimento tecnológico de um filtro de areia para irrigação localizada. Campinas: FEAGRI/UNICAMP, 2014. 169p. Doctoral Thesis

Mesquita, M.; Testezlaf, R.; Ramirez, J. C. S. The effect of media bed characteristics and internal auxiliary elements on sand filter head loss. Agricultural Water Management, v.115, p.178-185, 2012. http://dx.doi.org/10.1016/j.agwat.2012.09.003

Ramirez, J. C.; Testezlaf, R.; Mesquita, M. Processo da retrolavagem em filtros de areia usados na irrigação localizada. Engenharia Agrícola, v.31, p.1226-1237, 2011. http://dx.doi.org/10.1590/ S0100-69162011000600020

Rodgers, M.; Mulqueen, J.; Healy, M. G. Surface clogging in an intermittent stratified sand filter. Soil Science Society of America Journal, v.68, p.1827-1832, 2004. http://dx.doi.org/10.2136/sssaj2004.1827

Santos, M. B.; Mesquita, M.; Testezlaf, R. Aplicação de túnel de vento na avaliação de linhas de fluxo geradas por crepinas de filtros de areia. Engenharia Agrícola, v.33, p.548-559, 2013. http://dx.doi. org/10.1590/S0100-69162013000300011

Staden, S. J. V.; Haarhoff, J. The use of filter to determine filter cleanliness. Physics and Chemistry of the Earth, v.36, p.1135-1140, 2011. http://dx.doi.org/10.1016/j.pce.2011.07.067

Testezlaf, R. Filtros de areia aplicados à irrigação localizada: Teoria e prática. Engenharia Agrícola, v.28, p.604-613, 2008. http://dx.doi. org/10.1590/S0100-69162008000300020

Turan, M.; Sabah, E.; Gulsen. H. Influence of media characteristic on energy dissipation in filter backwashing. Environmental Science \& Technology, v.37, p.4288-4292, 2003. http://dx.doi.org/10.1021/ es020661r 